\title{
PENDIDIKAN KESEHATAN TENTANG PHBS JAMBAN SEHAT PADA WARGA DI DUSUN SEKAMPIL, KEC. RANTAU KELOYANG \\ KAB. BUNGO JAMBI
}

https://doi.org/10.33024/jkpm.v4i6.4477

\section{Erni Yuniati}

Dosen Program Studi DIII Keperawatan Akademi Keperawatan Setih Setio

Disubmit: 08 Juni 2021 Diterima: 13 Juli 2021 Diterbitkan: 01 Desember 2021

Email Korespondensi: e_yuniati@yahoo.com

\begin{abstract}
ABSTRAK
Perilaku Hidup Bersih dan Sehat (PHBS) merupakan perilaku yang dilakukan seseorang untuk selalu memperhatikan kebersihan, kesehatan dan berperilaku sehat. Program PHBS dilaksanakan dalam berbagai tatanan, salah satunya tatanan rumah tangga yaitu jamban sehat. Dampak dari pengetahuan dan pemahaman yang kurang tentang PHBS Jamban Sehat diduga menjadi salah satu factor penyebab tingginya kasus penyebaran penyakit menular seperti diare, DBD, dan lain-lain. Dusun Sekampil Kecamatan Rantau Keloyang adalah salah satu dusun yang terdapat di Kabupaten Bungo Provinsi Jambi. Penduduk setempat masih BAB/ BAK bukan di MCK atau tidak pada tempatnya. Penduduk lebih menyukai $B A B$ / BAK di sungai atau di kebun. Hal ini menunjukkan bahwa Perilaku Hidup Bersih dan Sehat (PHBS) di Dusun Sekampil terkait penyediaan jamban Sehat sangat rendah. Oleh karena itu diperlukan upaya pendidikan kesehatan untuk meningkatkan pengetahuan masyarakat di Dusun Sekampil tentang PHBS Jamban Sehat. Warga Dusun Sekampil dapat memahami tentang pentingnya pengetahuan dan pemahaman tentang PHBS Jamban Sehat. Kegiatan dilakukan dengan cara pendidikan kesehatan kepada para warga tentang PHBS Jamban Sehat di Dusun Sekampil, dengan metode pendidikan kesehatan ceramah dan tanya jawab menggunakan media power point dan leaflet. Berdasarkan kegiatan terdapat hasil yang signifikan pada pengetahuan warga sebelum dan sesudah diberikan pendidikan kesehatan tentang PHBS Jamban Sehat. Kegiatan ini memberikan hasil positif untuk warga di Dusun Sekampil, Kec. Rantau Keloyang, Kab. Bungo, Jambi tentang peningkatan pengetahuan PHBS Jamban Sehat.
\end{abstract}

Kata kunci : Pendidikan Kesehatan; PHBS Jamban Sehat.

\section{ABSTRACT}

Clean and Healthy Living Behavior (PHBS) is a behavior that a person does to always pay attention to cleanliness, health and healthy behavior. The PHBS program is implemented in various settings, one of which is the household arrangement, namely healthy latrines. The impact of a lack of knowledge and understanding of PHBS in Healthy Latrine is thought to be one of the factors causing the high prevalence of infectious diseases such as diarrhea, dengue fever, and others. Sekampil Hamlet, Rantau Keloyang District is one of the hamlets located in Bungo Regency, Jambi Province. Local residents still defecate 
I defecate not in the MCK or not in the right place. Residents prefer to defecate in the river or in the garden. This shows that the Clean and Healthy Lifestyle (PHBS) in Sekampil Hamlet related to the provision of healthy latrines is very low. Therefore, health education efforts are needed to increase public knowledge in Sekampil Hamlet about PHBS for Healthy Latrine. The residents of Dusun Sekampil can understand the importance of knowledge and understanding of PHBS for Healthy Latrine. The activity was carried out by means of health education to residents about PHBS Healthy Latrine in Sekampil Hamlet, with health education methods of lectures and questions and answers using power point media and leaflets. Based on the activity, there were significant results on the knowledge of the residents before and after being given health education about PHBS Healthy Latrine. This activity gave positive results for residents in Sekampil Hamlet, Kec. Rantau Keloyang, Kab. Bungo, Jambi about increasing knowledge of PHBS Healthy Latrine.

Keywords : Health Education; PHBS Healthy Latrine.

\section{PENDAHULUAN}

Sanitasi Total Berbasis Masyarakat (STBM) merupakan program pemerintah dalam rangka memperkuat upaya pembudayaan hidup bersih dan sehat, mencegah penyebaran penyakit berbasis lingkungan, meningkatkan kemampuan masyarakat serta mengimplementasikan komitmen pemerintah untuk meningkatkan akses air minum dan sanitasi dasar berkesinambungan dalam pencapaian Millennium Development Goals (MDGs). Upaya Sanitasi berdasarkan Keputusan Menteri Kesehatan RI Nomor 852/ Menkes/SK/IX/2008 yang disebut Sanitasi Total Berbasis Masyarakat (STBM) yaitu meliputi tidak buang air besar sembarangan (BABS), mencuci tangan pakai sabun, mengelola air minum dan 2 makanan yang aman, mengelola sampah dengan benar mengelola limbah air rumah tangga dengan aman (Kemenkes RI, 2014).

Perilaku Hidup Bersih dan Sehat (PHBS) merupakan perilaku yang dilakukan seseorang untuk selalu memperhatikan kebersihan, kesehatan dan berperilaku sehat. Program PHBS telah dilaksanakan sejak tahun 1996, oleh Pusat Penyuluhan Kesehatan Masyarakat yang saat ini disebut Pusat Promosi Kesehatan. Program PHBS dilaksanakan dalam berbagai tatanan, sepeti tatanan rumah tangga, tatanan pasar dan sebagainya.

Menurut hasil Riskesdas tahun 2013, Di Indonesia memang telah terjadi penurunan angka periode prevalence diare dari 9,0\% tahun 2007 menjadi $3,4 \%$ pada tahun 2014. Kelompok umur balita merupakan kelompok umur yang paling tinggi menderita diare. Karakteristik diare balita tertinggi terjadi pada kelompok umur $12-23$ bulan $(7,4 \%)$ laki-laki $(5,4 \%)$, tinggal didaerah pedesaan $(5,8 \%)$, dan kelompok indeks kepemilikan akses terhadap air bersih dan jamban sehat terbawah $(6,4 \%)$ (Riskesdas, 2013).

Provinsi Jambi merupakan provinsi ke-6 terendah dengan proporsi rumah tangga ber-PHBS di Indonesia yaitu sebesar 20\%. Angka tersebut jauh dari target yang diharapkan. Dari cakupan ruta ber PHBS pada daerah perkotaan yang rata-rata nasional mencapai $42,3 \%$ dan ruta ber PHBS daerah pedesaan yang jauh lebih rendah sebesar 22,9\%. Apabila merujuk hal ini bias disebutkan bahwa rumah tangga ber PHBS di Provinsi Jambi masih sangat rendah (Saputra E N, Kalsum U dan Ekawati N Y, 2018). 
Dusun Sekampil Kecamatan Rantau Keloyang adalah salah satu dusun yang terdapat di Kabupaten Bungo Provinsi Jambi. Pemukiman penduduk di Dusun tersebut cukup padat. Penduduk setempat masih BAB/ BAK bukan di MCK atau tidak pada tempatnya. Penduduk lebih menyukai BAB/ BAK di sungai atau di kebun. Bagi penduduk disekitarnya, hal ini mudah dipahami dikarenakan membuang hajat di sungai dan di kebun merupakan kebiasaan yang sudah turun-temurun dari sejak zaman dulu.

Kebiasaan tersebut tentunya bertentangan dengan azas perilaku hidup bersih dan sehat dikarenakan sungai juga merupakan salah satu media tempat penularan penyakit apalagi jika sungai digunakan untuk pembuangan tinja tentunya sungai akan terkontaminasi dan merupakan media penyebaran kuman seperti kuman penyebab diare dan penyakit lain. Hal ini menunjukkan bahwa Perilaku Hidup Bersih dan Sehat (PHBS) di Dusun Sekampil terkait penyediaan jamban Sehat sangat rendah.

Manfaat jamban belum diketahui sepenuhnya oleh masyarakat sehingga mereka seenaknya saja membuang tinja disembarang tempat dan masalah penggunaan jamban keluarga juga dipengaruhi oleh faktor pendidikan, pengetahuan, pekerjaan, sikap, pendapatan masyarakat, ketersediaan lahan dan ketersediaan air bersih. Menyikapi hal tersebut maka, faktor pencegahan dan promotif lebih memegang peranan penting.

Dampak dari pengetahuan dan pemahaman yang kurang tentang PHBS diduga menjadi salah satu factor penyebab tingginya kasus penyebaran penyakit menular seperti diare, DBD, dan lain-lain. Oleh karena itu diperlukan upaya pendidikan kesehatan untuk meningkatkan pengetahuan warga dusun Sekmpil tentang PHBS Jamban Sehat ini.

Tujuan umum dari kegiatan pendidikan kesehatan ini yaitu warga Dusun Sekampil dapat mengerti tentang pentingnya pengetahuan dan pemahaman tentang PHBS Jamban Sehat. Tujuan khususnya yaitu Warga Dusun Sekampil mengetahu tentang pengertian PHBS, ruang lingkup PHBS, tatanan PHBS, 10 perilaku PHBS. Warga Dusun Sekampil mengetahui tentang pengertian PHBS di RumahTangga, manfaat PHBS di rumah tangga, sasaran PHBS di Rumah Tangga serta Warga Dusun Sekampil mengetahui dan memahami pengertian Jamban sehat, syarat jamban sehat menurut Depkes RI, dampak BAB sembarangan, cara memelihara jamban sehat, cara memilih jamban sehat, jenis jamban sehat, tempat yang dilarang sebagai tempat $B A B$, cara penularan kuman penyakit.

\section{MASALAH}

Masih banyak ditemukan masyarakat di Dusun Sekampil yang kurang mengerti tentang kesehatan lingkungan khususnya terkait dengan penerapan perilaku hidup bersih dan sehat terkait dengan ketersediaan jamban sehat. Untuk itu perlu dilakukan kegiatan penyuluhan kesehatan tentang PHBS (Perilaku Hidup Bersih dan Sehat) Khususnya jamban sehat. Penyuluhan kesehatan tentang PHBS Jamban sehat meliputi pengertian PHBS, ruang lingkup PHBS, tatanan PHBS, 10 perilaku PHBS, pengertian PHBS di RumahTangga, manfaat PHBS di rumah tangga, sasaran PHBS di RumahTangga, pengertian Jamban sehat, syarat jamban sehat menurut Depkes RI, dampak BAB sembarangan, cara memelihara jamban sehat, cara memilih jamban sehat, jenis jamban sehat, tempat yang dilarang sebagai tempat $\mathrm{BAB}$, cara penularan kuman penyakit. Warga di wilayah Dusun Sekampil terdiri dari berbagai latar belakang pendidikan dan jenis suku. 
Pemahaman yang kurang tentang PHBS Jamban Sehat mendasari alasan oleh penulis untuk melakukan pengabdian kepada masyarakat ini.

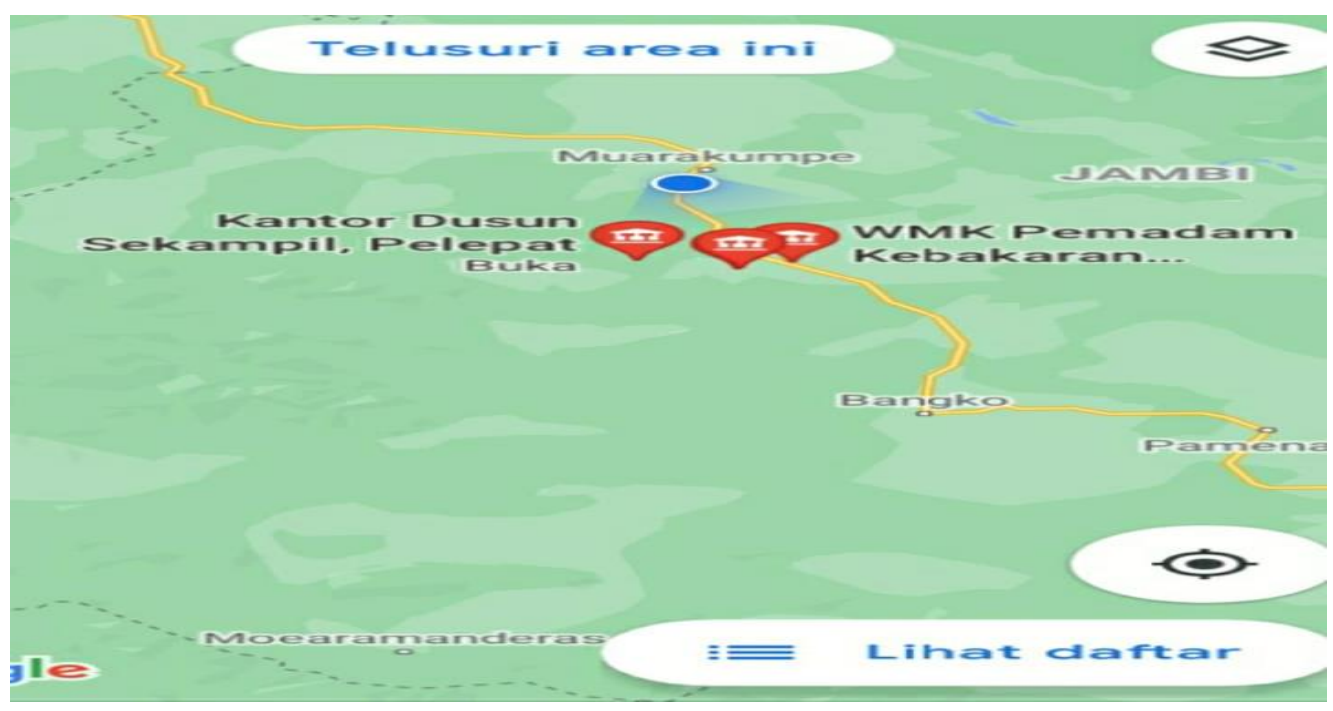

Gambar 2.1 Peta Lokasi Kegaiatan

\section{METODE}

Metode penerapan iptek yang dilakukan adalah dengan memberikan penyuluhan tentang PHBS JambanSehat Di Dusun Sekampil Kec.Rantau Keloyang, Kab. Bungo, Semua warga Dusun Sekampil yang hadir bias mengikuti kegiatan penyuluhan tentang PHBS Jamban Sehat. Subyek dalam kegiatan pengabdian kepada masyarakat ini adalah warga Dusun Sekampil. Pada tahap awal dilakukan pengukuran tingkat pengetahuan yang berhubungan dengan PHBS Jamban Sehat. Menggunakan pertanyaan terkait PHBS Jamban Sehat, seperti definisi PHBS, ruang lingkup PHBS, tatanan PHBS dan perilaku PHBS. Dengan menggunakan pertanyaan-pertanyaan secara langsung kepada warga yang mengikuti Pendidikan Kesehatan.

Berdasarkan hasil pre test yang didapatkan, selanjutnya diberikan kegiatan dalam bentuk pendidikan kesehatan tentang PHBS Jamban Sehat. Penjelasan materi disampaikan oleh nara sumber dengan menggunakan metode power point dan leaflet. Setelah kegiatan selesai dilakukan, subyek diberikan pertanyaan kembali sebagai (post test) dengan pertanyaan yang sama.

\section{HASIL DAN PEMBAHASAN}

\section{HASIL}

Pendidikan kesehatan tentang PHBS Jamban Sehat di wilayah dusun Sekampil berjalan sesuai harapan (lancar). Warga yang hadir 67 orang. Pengetahuan subyek meningkat, subyek lebih memahami tentang PHBS Jamban Sehat, yang awalnya tidak memahami tentang PHBS. Jamban Sehat setelah diberikan pendidikan kesehatan warga menjadi mengerti tentang PHBS Jamban Sehat.warga memiliki pemahaman yang baik tentang PHBS Jamban Sehat. Peningkatan rata-rata berkisar 75\% sebelum dan sesudah dilakukan tindakan pendidikan kesehatan. Hal ini dipengaruhi oleh factor 
tingkat pendidikan dari masing-masing warga.

Dari hasil evaluasi kegiatan yang telah dilaksanakan didapatkan hasil sesuai dengan tujuan kegiatan adalah sebagaiberikut :

1. $75 \%$ warga Dusun Sekampil mengetahui tentang pengertian PHBS, ruang lingkup PHBS, tatanan PHBS, 10 perilaku PHBS.

2. $75 \%$ warga Dusun Sekampil mengetahui tentang pengertian PHBS di Rumah Tangga, manfaat PHBS di rumah tangga, sasaran PHBS di Rumah Tangga.

3. 75\% warga Dusun Sekampil mengetahui tentang dampak BAB sembarangan, cara memelihara jamban sehat, cara memilih jamban sehat, jenis jamban sehat, tempat yang dilarang sebagai tempat $B A B$, cara penularan kuman penyakit.

\section{PEMBAHASAN}

Perilaku Hidup Bersih dan Sehat merupakan hal yang sangat penting untuk diterapkan dalam perilaku sehari-hari dalam kehidupan individu, keluarga, kelompok dan masyarakat. Karena Perilaku Hidup Bersih dan Sehat adalah suatu upaya pencegahan terhadap penyakit. Jika individu, keluarga, kelompok dan masyarakat tidak menerapkan perilaku hidup bersih dan sehat maka akan banyak akibat ataupun penyakit yang ditimbulkan. Salah satu Perilaku hidup bersih dan sehat yang belum diterapkan dan masih banyak terjadi disekitar kita adalah PHBS di Tatanan Rumah Tangga yaitu tentang ketersediaan Jamban sehat. Jamban sehat sangat penting kaitannya dengan perilaku hidup bersih dan sehat. Ketika seseorang tidak membuang hajat pada tempat yang sesuai atau BAB di sungai, maka hal tersebut dapat menyebabkan penularan penyakit khususnya penyakit yang ditularkan oleh bakteri yang terkandung dalam kotoran manusia/ feses.

Dalam Penelitian yang dilakukan oleh Irianty $H$, Hayati $R$ dan Riza $\mathrm{Y}$, tentang Hubungan Perilaku Hidup Bersih dan Sehat (PHBS) dengan Kejadian Diare pada Balita, menyebutkan bahwa Penggunaan Jamban Sehat dengan Kejadian Diare responden yang menggunakan jamban sehat di wilayah kerja Puskesmas Martapura Barat sebanyak 26 responden (34,2\%), sedangkan responden yang tidak menggunakan jamban sehat sebanyak 50 responden $(65,8 \%)$. Angka kejadian diare pada balita dengan responden tidak menggunakan jamban sehat sehat sebanyak 36 (72\%), dan tidak mengalami diare sebanyak 14 (28\%). Sedangkan angka kejadian diare pada balita dengan responden menggunakan jamban sehat sebanyak $12(46,2 \%)$ dan tidak mengalami diare sebanyak 14 (53,8\%). Hasil analisis dengan uji Chi Squaredidapatkan bahwa ada hubungan antara penggunaan jamban sehat dengan kejadian diare pada balita (Irianty H, Hayati R dan Riza Y, 2018).

Oleh sebab itu pengetahuan tentang PHBS Jamban sehat sangat penting artinya untuk diketahui oleh individu, keluarga, kelompok dan masyarakat. Banyaknya warga Dusun Sekampil yang tidak tahu tentang PHBS khususnya Jamban sehat, disebabkan oleh pengetahuan warga Dusun Sekampil yang kurang tentang PHBS Jamban Sehat, seperti misalnya masih terdapat banyak warga yang membuang hajat kesungai, dimana sungai digunakan juga untuk sumber air minum. Dikarenakan banyak factor diantaranya warga kurang terpapar dengan pendidikan-pendidikan kesehatan atau informasi tentang PHBS khusunya Jamban sehat. Untuk itu pemberian penyuluhan tentang PHBS Jamban Sehat sangat bermanfaat untuk merubah pengetahuan dan prilaku kesehatan warga Dusun Sekampil tersebut.

Hasil pengabdian ini sejalan dengan hasil penelitian yang dilakukan oleh Wijaya A, Sary L dan Yanti L (2014), tentang Pengaruh penyuluhan terhadap 
pengetahuan dan sikap tentang perilaku hidup bersih dan sehat (PHBS) pada tatanan rumah tangga di Desa Mandah Wilayah Kerja Puskesmas Branti Raya Kecamatan Natar Kab. Lampung Selatan, menyatakan bahwa ada pengaruh penyuluhan terhadap pengetahuan tentang Perilaku Hidup Bersih dan Sehat (PHBS) pada tatanan rumah tangga (Wijaya A dkk, 2013).

Sejalan juga dengan hasil Penelitian Apriliana F, Amirus $\mathrm{K}$ dan Febrianti C A. 2014. Hubungan Perilaku Cuci tangan pakai sabun, konsumsi jajan sehat dan penggunaan jamban sehat dengan kejadian Hepatitis A pada siswa di Madrasah Aliyah Raudhatul Huda Al Islami Kabupaten Pesawaran yang menunjukkan hasil bahwa terdapat hubungan perilaku penggunaan jamban sehat dengan kejadian Hepatitis A pada siswa (Apriliana F, dkk, 2014).

Sejalan juga dengan hasil Penelitian Sani N, Abidin Z. 2015. Hubungan perilaku hidup bersih dan sehat ibu balita dengan kejadian diare akut pada balita di Wilayah kerja Puskesmas Candra Mukti Kabupaten Tulang Bawang Barat, menunjukkan hasil bahwa terdapat hubungan kebiasaan Buang Air Besar dengan kejadian diare akut pada Balita di Wilayah kerja Puskesmas Candra Mukti Kab. Tulang Bawang Barat.

Sejalan dengan penelitian Febriani W, Samino dan Sari N, tahun 2016 tentang Faktor yang mempengaruhi perubahan perilaku stop Buang Air Besar Sembarangan (BABS) : studi pada program STBM di Desa Sumbersari Metro Selatan menunjukkan bahwa keberhasilan program STBM dipengaruhi oleh akses/ketersediaan sanitasi, pengetahuan, dukungan sosial, sikap dan keyakinan masyarakat di Desa Sumbersari Kota Metro tersebut.

Sejalan dengan Penelitian Puspitasari D A, Nuryati D D dan Sary L. 2015 tentang Hubungan kondisi saluran pembuangan air limbah, sarana air bersih dan jamban dengan kejadian diare pada balita di Wilayah kerja Puskesmas Simpang Agung Kec. Seputih Agung Lampung Tengah menunjukkan hasil bahwa terdapat hubungan jamban sehat dengan kejadian diare pada balita.

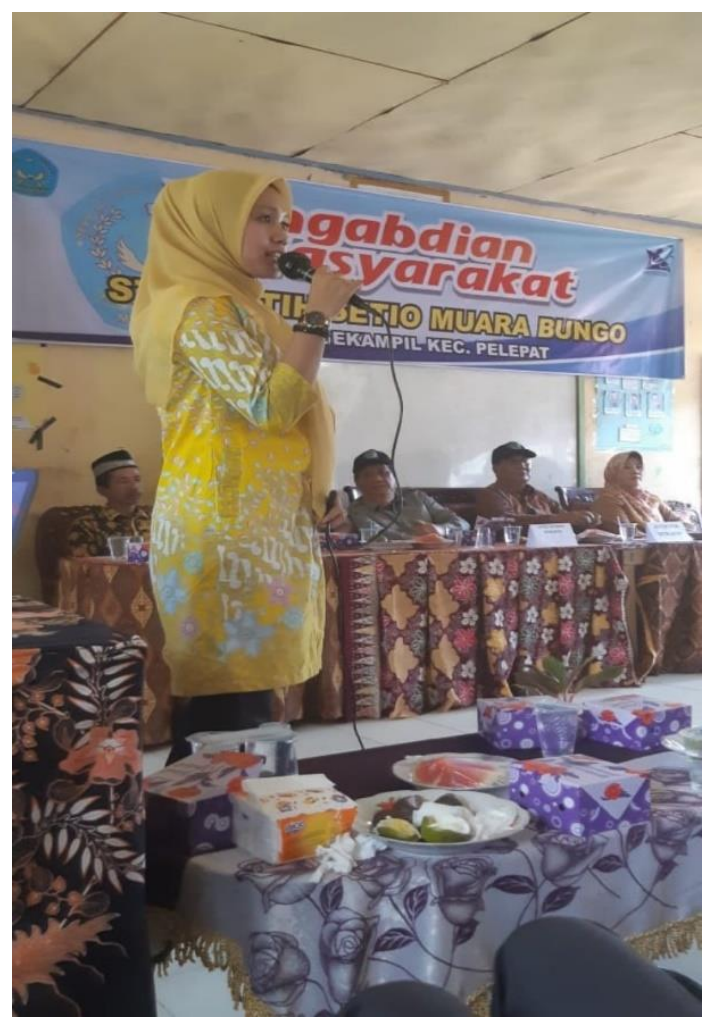



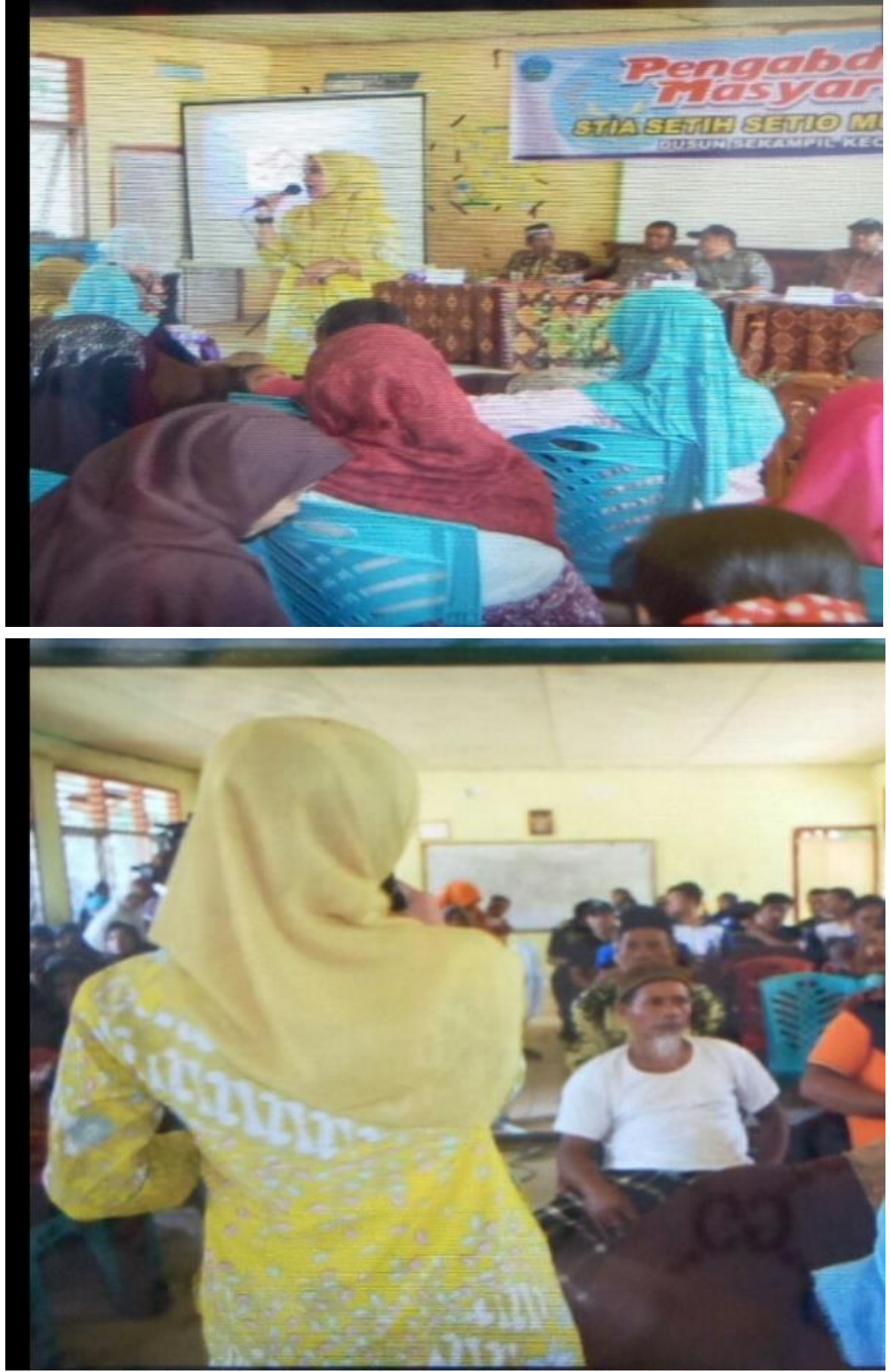

Gambar 4.1 Gambar Pelaksanaan Kegiatan

\section{KESIMPULAN}

Berdasarkan kegiatan yang telah dilaksanakan, dapat ditarik kesimpulan dalam kegiatan pengabdian kepada masyarakat di Dusun Sekampil Kecamatan Rantau Keloyang ini adalah adanya peningkatan pengetahuan tentang PHBS Jamban Sehat pada subyek denga npeningkatan rata-rata sebesar $75 \%$. 


\section{DAFTAR PUSTAKA}

Apriliana F, Amirus K dan Febrianti C A. 2014. Hubungan Perilaku Cuci tangan pakai sabun, konsumsi jajan sehat dan penggunaan jamban sehat dengan kejadian Hepatitis A pada siswa di Madrasah Aliyah Raudhatul Huda Al Islami Kabupaten Pesawaran. Jurnal Dunia Kesmas Volume 3. Nomor 4. Oktober 2014 (257-262).

Febriani W, Samino dan Sari N. 2016. Faktor yang mempengaruhi perubahan perilaku stop Buang Air Besar Sembarangan (BABS) : studi pada program STBM di Desa Sumbersari Metro Selatan. Jurnal Dunia Kesmas Volume 5. Nomor 3. Juli 2016 (121-130).

Irianty H, Hayati R \& Riza Y. 2018. Hubungan Perilaku Hidup Bersih dan Sehat (PHBS) dengan Kejadian Diare pada Balita. ISSN 2503-1139, Volume 8, Nomor 1 Juni 2018.

Kemenkes Ri. 2013. Riset Kesehatan Dasar; RISKESDAS. Jakarta: Balitbang Kemenkes $\mathrm{Ri}$ I. Profil Kesehatan Indonesia tahun 2014. Jakarta : Kemenkes RI; 2015.

Puspitasari D A, Nuryati D D dan Sary L. 2015. Hubungan kondisi saluran pembuangan air limbah, sarana air bersih dan jamban dengan kejadian diare pada balita di Wilayah kerja Puskesmas Simpang Agung Kec. Seputih Agung Lampung Tengah. Jurnal Dunia Kesmas Volume 4, Nomor 3 Juli 2015 (157-162).

Sani N, Abidin Z. 2015. Hubungan perilaku hidup bersih dan sehat ibu balita dengan kejadian diare akut pada balita di Wilayah kerja Puskesmas Candra Mukti Kabupaten Tulang Bawang Barat.

Saputra E N, Kalsum U danEkawati N Y, 2018. UpayameningkatkanpengetahuandanketerampilanPerilakuHidupBersihd anSehat (PHBS) orang rimbamelaluipembinaan PHBS RumahTangga. JPPM ISSN 2549-8347, Vol. 2 No.2 September 2018.

Wijaya A, Sary L dan Yanti L. (2014). Pengaruh penyuluhan terhadap pengetahuan dan sikap tentang perilaku hidup bersih dan sehat (PHBS) pada tatanan rumah tangga di Desa Mandah Wilayah Kerja Puskesmas Branti Raya Kecamatan Natar Kab. Lampung Selatan. Jurnal Dunia Kesmas Volume 3. Nomor 1. Januari 2014 (62-68). 